\title{
STUDI PENGARUH GEMPA TERHADAP VARIASI PANJANG TULANGAN PENYALURAN PADA SAMBUNGAN BALOK DAN KOLOM TEPI
}

\author{
Febrin Anas Ismail ${ }^{1}$
}

\begin{abstract}
ABSTRAK
Pada struktur bangunan yang dimiliki masyarakat kita, sering dijumpai struktur tersebut kurang memenuhi persyaratan dalam hal teknis. Sehingga saat terjadi Gempa pada tanggal 6 Maret 2007 menimbulkan kerusakan pada konstruksi bangunan baik perumahan rakyat, fasilitas umum maupun bangunan pemerintah. Kerusakan yang terbanyak didominasi oleh perumahan rakyat yang tergolong non-engineered building, dimana perencanaannya dilakukan berdasarkan pengalaman turun temurun. Salah satu bentuk kerusakan pada komponen struktural bangunan yang terjadi akibat gempa terjadi pada bagian sambungan antara balok dan kolom. Hal ini diakibatkan karena tidak memadainya panjang tulangan penyaluran Oleh karena itu perlu dikaji seberapa besar pengaruh panjang penyaluran tulangan terhadap beban gempa pada bangunan rumah sederhana.

Penelitian ini menggunakan portal berbentuk " $\mathrm{L}$ " dengan variasi panjang penyaluran tulangan pada sambungan balok dan kolom tepi sebesar $40 \mathrm{~cm}$ dan $20 \mathrm{~cm}$. Untuk mengetahui mutu bahan yang digunakan, terlebih dahulu dilakukan tes material untuk agregat halus dan kasar.

Pengujian sampel dilakukan dengan memberi beban horizontal dengan metode static pushover sebagai bentuk dari beban gempa. Dari hasil pengujian portal didapatkan besarnya pengaruh variasi penyaluran tulangan pada sambungan balok dan kolom tepi, sehingga didapatkan panjang penyaluran tulangan yang baik untuk digunakan.
\end{abstract}

Kata Kunci : gempa, panjang penyaluran.

\section{PENDAHULUAN}

Gempa bumi merupakan suatu fenomena alam yang tidak dapat dihindari, tidak dapat diramalkan kapan terjadi dan berapa besarnya, serta akan menimbulkan kerugian baik harta maupun jiwa bagi daerah yang ditimpanya dalam waktu relatif singkat.

Indonesia merupakan kawasan dengan intensitas kegempaan yang aktif di dunia, karena di wilayah ini melintas Jalur Circum Pasifik dan Jalur Hindia - Himalaya. Selain itu, keberadaan tiga lempeng tektonik sangat mempengaruhi resiko kegempaan di Indonesia. Setidak-tidaknya empat ratus gempa terjadi setiap tahun yang meliputi gempa besar, sedang dan kecil. Untuk tahun 2004-2007, terjadi beberapa gempa bumi yang dapat dikatakan berkategori besar dengan selang waktu yang berdekatan. Diantara beberapa kejadian gempa tersebut, mengakibatkan dampak yang merugikan baik dalam hal intensitas kerusakan pada bangunan maupun korban jiwa yang diakibatkannya.

Dari aspek kerusakan bangunan, hasil kajian terhadap kejadian gempa 6 Maret 2007 itu dapat disimpulkan bahwa kerusakan yang paling besar dialami oleh bangunan rumah penduduk. Selanjutnya hasil kajian menjelaskan bahwa penyebab utama kerusakan adalah diakibatkan oleh kurang terpenuhinya persyaratan bahan yang digunakan dan persyaratan teknis yang meliputi kualitas konstruksi, seperti sambungan pada elemen struktur.

\footnotetext{
${ }^{1}$ Staf Pengajar Jurusan Teknik Sipil Fakultas Teknik Universitas Andalas, e-mail: febrin@ft.unand.ac.id
} 
Persyaratan teknis pada bangunan merupakan persyaratan dasar yang harus dipenuhi oleh suatu bangunan tahan gempa. Karena seperti yang kita ketahui gempa bumi menyebabkan goyangan pada tanah sehingga dasar bangunan diatasnya akan ikut tergoyang. Jika bangunan tersebut tidak terikat dengan kuat antara elemen-elemen strukturnya, maka setiap elemen akan terlepas dan menyebabkan keruntuhan pada bangunan tersebut.

Salah satu syarat bangunan tahan gempa adalah terjaganya sambungan antara elemen struktur mulai dari struktur bagian bawah sampai dengan struktur bagian atas. Salah satu kesalahan konstruksi yang paling banyak ditemukan adalah kesalahan pada sambungan kolom dengan ring balok. Pada sambungan tersebut tidak diberi tulangan penyaluran, walaupun ada tetapi tidak mencukupi/kurang dari persyaratan $40 \mathrm{~cm}$. Seperti yang kita ketahui, untuk konstruksi beton bertulang, sambungan antara elemen struktur biasanya dilakukan dengan memberikan suatu panjang penyaluran tulangan antara elemen struktur agar saling mengikat satu sama lainnya.

Oleh sebab itu, untuk mengatahui sejauh mana pengaruh sambungan elemen struktur antara kolom dan balok ring terhadap beban gempa yang diberikan, perlu diadakan suatu percobaan dengan skala penuh. Percobaan skala penuh adalah cara yang paling produktif dan efektif untuk memperoleh informasi mengenai apa yang terjadi pada bangunan kalau digoncang gempa. Percobaan skala penuh yang paling tepat adalah memeriksa dengan seksama dan belajar dari kerusakan bangunan akibat gempa. Sampai beberapa tahun yang lalu, cara inilah yang digunakan untuk merencanakan bangunan non-engineered agar tahan gempa, yaitu belajar dari kerusakan di masa lalu.

Penelitian bertujuan untuk melakukan pengkajian mengenai sambungan tulangan antara balok dan kolom tepi dengan variasi tulangan penyaluran $40 \mathrm{~cm}$ dan $20 \mathrm{~cm}$. Manfaat dari penelitian ini adalah agar kita dapat mengetahui pola sambungan manakah yang baik untuk digunakan. Sehingga masyarakat dapat menerapkan pola sambungan yang baik untuk digunakan dalam mendirikan bangunan.

\section{PELAKSANAAN PENGUJIAN}

\subsection{Perencanaan Benda Uji}

Benda uji yang akan diteliti adalah model skala penuh (full scale model) variasi panjang penyaluran tulangan pada sambungan kolom dan balok tepi. Pemilihan variasi panjang tulangan ini bertujuan untuk menentukan panjang penyaluran tulangan yang baik untuk digunakan. Bentuk model yang diambil sebagai model benda uji (sampel) adalah balok kolom tepi dari rumah sederhana, seperti pada Gambar 1.

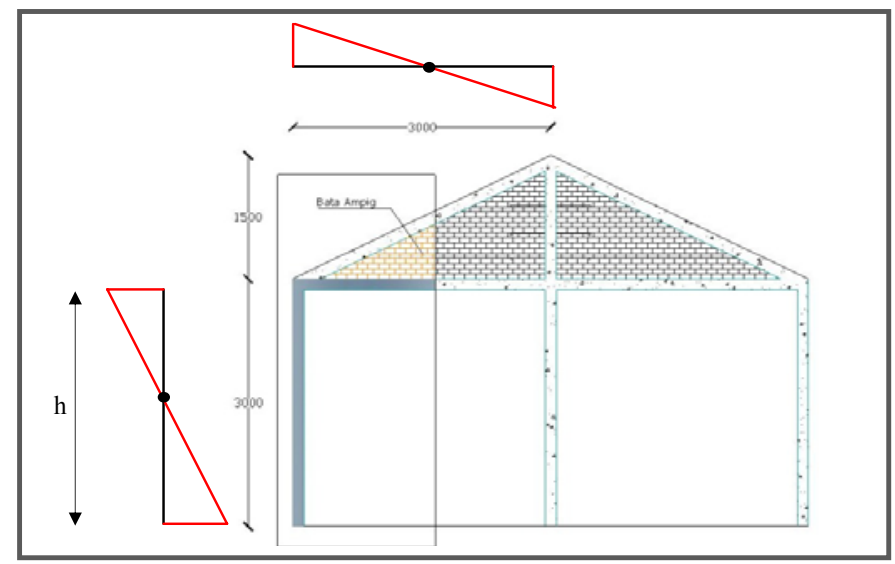

Gambar 1. Daerah yang Ditinjau 
Pada bagian tengah balok dan bagian tengan kolom, jika diberi beban lateral, maka momen pada tengah bentang tersebut bernilai nol. Berdasarkan hal tersebut maka pada tengah bentang balok dengan momen bernilai nol dapat diganti dengan engsel/ rol. Benda uji dibuat sesuai dengan skala yang sebenarnya (full scale specimen), agar komponen struktur selama menerima beban uji dapat mneggambarkan perilaku yang sebenarnya.

Jenis perletakan yang digunakan ada dua macam, yaitu perletakan jepit dan rol. Perletakan jepit untuk kolom sedangkan rol untuk balok. Balok diberi perletakan rol agar dapat bergerak bebas arah sumbu global $x$.

Pada eksperimen ini dibuat 2 (dua) buah portal dengan dengan variasi panjang tulangan penyaluran pada sambungan aadalah sebagai berikut :

1. Panjang penyaluran tulangan $40 \mathrm{~cm}$ Tulangan kolom dilebihkan sepanjang $40 \mathrm{~cm}$ dari tinggi kolom sebagai tulangan penyaluran, seperti pada Gambar 2.

Tinggi Portal

$3,50 \mathrm{~m}$

Volume Portal : $0,0806 \mathrm{~m}^{3}$

Panjang penyaluran : $40 \mathrm{~cm}$

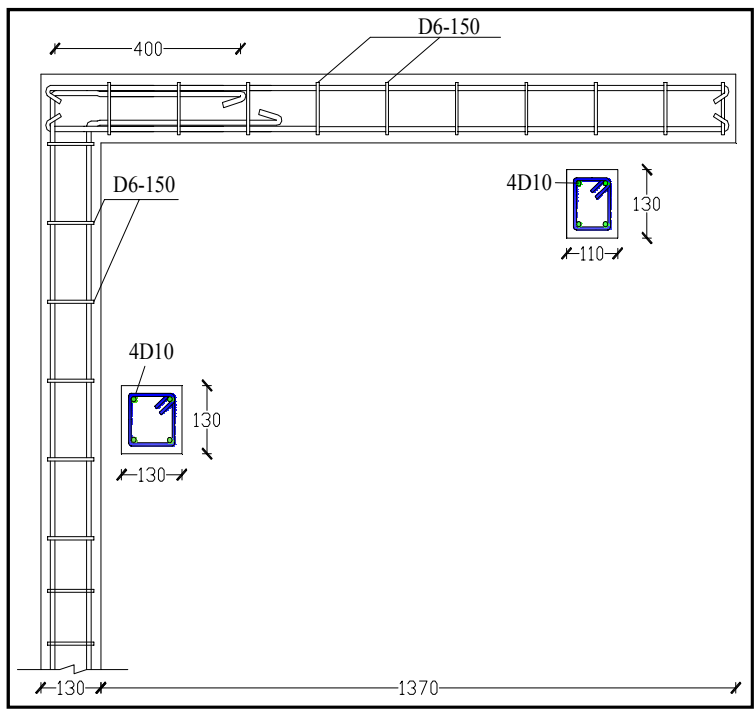

Gambar 2. Detail Penulangan Benda Uji dengan Panjang Penyaluran $40 \mathrm{~cm}$

2. Panjang penyaluran tulangan $20 \mathrm{~cm}$

Tulangan kolom dilebihkan sepanjang $20 \mathrm{~cm}$ dari tinggi kolom sebagai tulangan penyaluran. Seperti pada Gambar 3.

Tinggi Portal

$3,50 \mathrm{~m}$

Volume Portal

: $0,0806 \mathrm{~m} 3$

Panjang penyaluran : $20 \mathrm{~cm}$

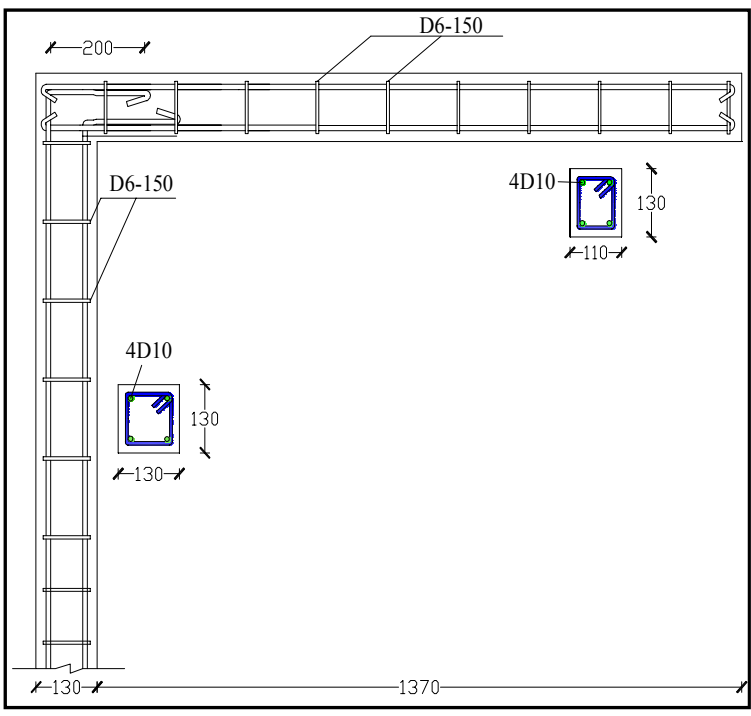

Gambar 3. Detail Penulangan Benda Uji Dengan Panjang Penyaluran $20 \mathrm{~cm}$ 


\subsection{Material Beton dan Baja}

Campuran beton menggunakan semen normal (semen tipe 1), yaitu semen yang dapat digunakan secara umum tanpa persyaratan tertentu. Beton yang digunakan untuk benda uji direncanakan dengan mutu $175 \mathrm{~kg} / \mathrm{cm}^{2}$ (K-175) dengan perbandingan campuran 1 semen : 2 pasir : 3 kerikil. Baja tulangan yang digunakan terdiri dari tulangan ulir dan tulangan polos dengan tegangan leleh aktual $240 \mathrm{MPa}$.

\subsection{Instrumentasi dan Setup Pengujian}

Alat ukur yang digunakan pada penelitian ini adalah dial perpindahan. Sedangkan alat uji pembebanan yang digunakan dalam penelitian adalah actuator dengan kapasitas 5 ton, digunakan untuk memberikan beban horizontal pada benda uji. Setup pengujian dan sistem pembebanan pengujian dapat dilihat pada Gambar 4.

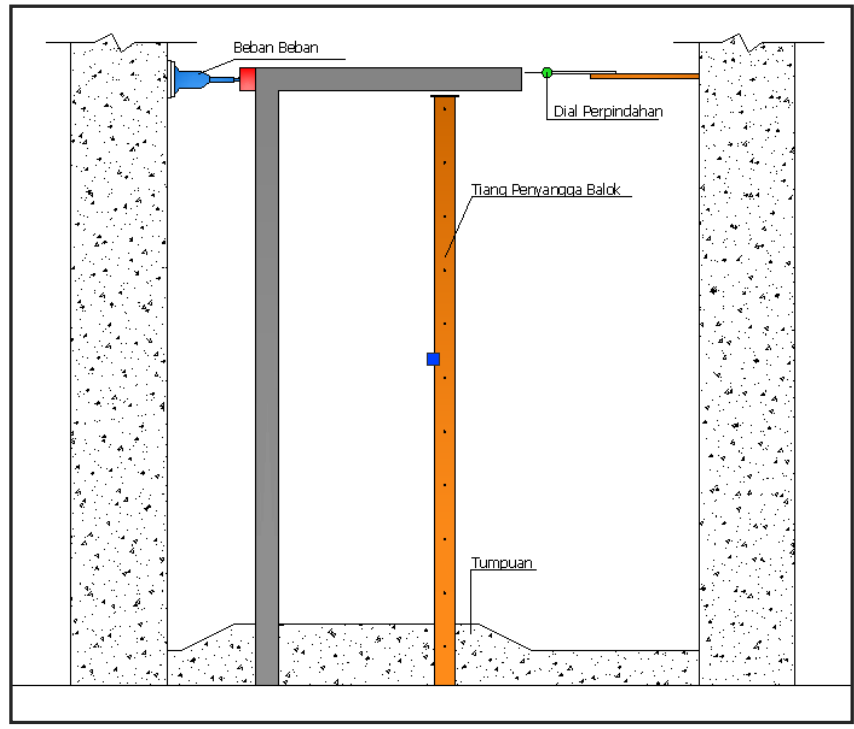

Gambar 4. Setup Pengujian Benda Uji

Pengujian dilakukan dengan langkah - langkah sebagai berikut :

a. Memakukan papan pada bidang masif sebagai peredam dan beban dari actuator tidak langsung bersentuhan dengan bidan masif.

b. Beban pushover (actuator) yang telah dipersiapkan, diposisikan pada bidang masif dalam arah horizontal di titik benda uji yang akan diberikan dorongan (Gambar 5).

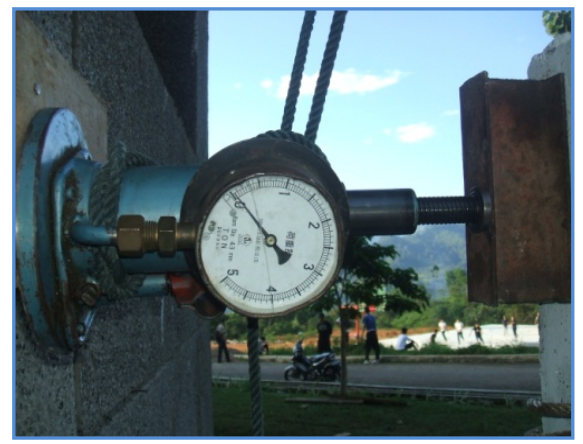

Gambar 5. Actuator 
c. Setelah posisi beban tepat, maka kemudian dipasang dial untuk membaca besar perpindahan $(\delta)$ yang terjadi pada ujung balok (Gambar 6).

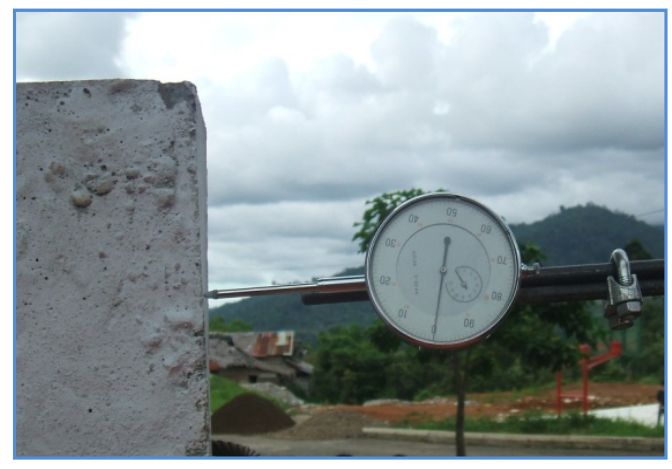

Gambar 6. Dial Perpindahan

d. Dengan memberikan beban pushover, benda uji didorong sebesar $P$ secara bertahap sampai benda uji mengalami perubahan (keruntuhan).

e. Setelah itu diamati dan dicatat perubahan yang terjadi baik itu pada kolom dan balok dengan mencatat besar deformasi yang terjadi atau pola retak yang ditimbulkan pada benda uji.

f. Prosedur di atas dilakukan kepada kedua benda uji. Dokumentasikan perubahan yang terjadi pada setiap benda uji dan dilakukan analisa manakah yang lebih baik (panjang penyaluran 40 $\mathrm{cm}$ atau $20 \mathrm{~cm}$ ).

\section{ANALISIS DAN PEMBAHASAN HASIL PENGUJIAN}

\subsection{Hubungan Beban - Perpindahan}

Kurva pushover untuk hubungan beban $(P)$ dan besarnya deformasi $(\delta)$ yang terjadi pada portal untuk panjang penyaluran $40 \mathrm{~cm}$ ditunjukkan pada Gambar 7. Pada gambar tersebut terlihat bahwa nilai beban $P$ yang dicapai adalah $190 \mathrm{~kg}$ dengan perpindahan $112 \mathrm{~mm}$. Pada grafik tampak bahwa nilai beban $\mathrm{P}$ masih mengalami kenaikan dan belum tampak adanya penurunan beban.

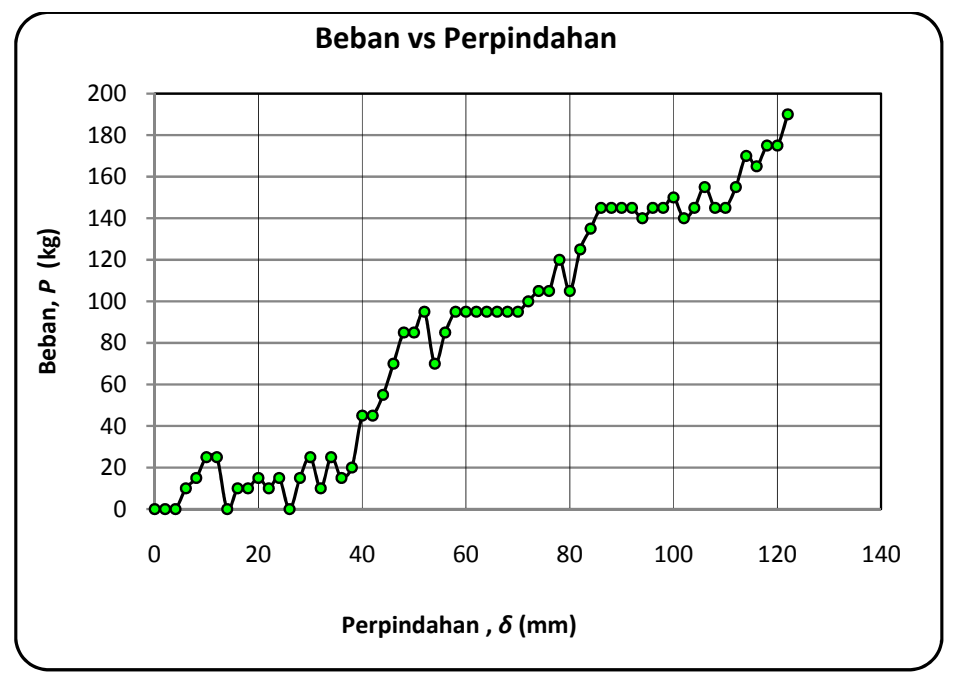

Gambar 7. Kurva Pushover untuk Panjang Penyaluran 40 cm 
Pada panjang penyaluran $20 \mathrm{~cm}$, beban maksimum $P$ yang dapat dicapai adalah $155 \mathrm{~kg}$ pada perpindahan $88 \mathrm{~mm}$. Setelah pembebanan sebesar $155 \mathrm{~kg}$ tersebut beban $P$ mengalami penurunan beban sebesar $30 \mathrm{~kg}$ sehingga beban $P$ menjadi 125 pada perpindahan $90 \mathrm{~mm}$ dan $94 \mathrm{~mm}$. Kondisi tersebut dapat dilihat pada Gambar 8.

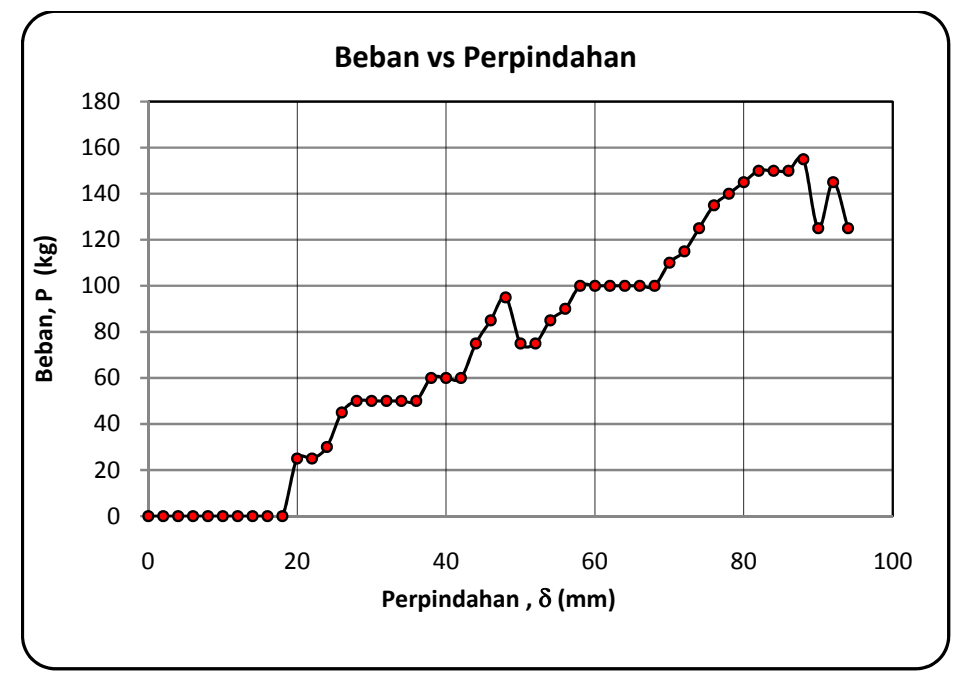

\section{Gambar 8. Kurva Pushover untuk Panjang Penyaluran 20 cm}

Analisa statik nonlinear merupakan prosedur analisa untuk mengetahui perilaku keruntuhan suatu bangunan terhadap gempa, yang dikenal dengan istilah pushover atau analisa beban dorong statik. Tujuan analisa pushover adalah untuk memperkirakan gaya maksimum dan deformasi yang terjadi serta untuk memperoleh informasi bagian mana saja yang kritis.

Beban P maksimum untuk panjang penyaluran $40 \mathrm{~cm}$ adalah $190 \mathrm{~kg}$ dengan besar perpindahan maksimum $\left(\delta_{\text {maks }}\right)$ adalah $122 \mathrm{~mm}$. Sedangkan pada panjang penyaluran $20 \mathrm{~cm}$ beban P maksimum adalah $155 \mathrm{~kg}$ dengan perpindahan maksimum pada balok $88 \mathrm{~mm}$.

Dari hasil tersebut dapat dianalisa beberapa hal yang berkaitan dengan hubungan beban dan perpindahan yaitu :

1. Panjang penyaluran $40 \mathrm{~cm}$ dapat menahan beban $(P)$ lebih besar dibandingkan dengan panjang penyaluran $20 \mathrm{~cm}$.

2. Perpindahan maksimum $\left(\delta_{\text {maks }}\right)$ dan penurunan beban $(P)$ pada panjang penyaluran $20 \mathrm{~cm}$ lebih cepat terjadi dibandingkan panjang penyaluran $40 \mathrm{~cm}$. Hal ini membuktikan bahwa panjang penyaluran $40 \mathrm{~cm}$ lebih bersifat liat. Sehingga perpindahan maksimum lebih lama terjadi dan penurunan beban $P$ secara tiba-tiba dapat dihindari.

\subsection{Pola Retak}

Selain besar deformasi $(\delta)$ yang terjadi pada model uji akibat pemberian beban pushover $(P)$, juga diperoleh visualisasi tentang pola retak atau keruntuhan yang terjadi pada sambungan balok dan kolom setelah pengujian di laboratorium. Gambar-gambar berikut menunjukkan pola retak hasil pengujian. Gambar 9 dan Gambar 10 untuk panjang penyaluran $40 \mathrm{~cm}$ dan Gambar 11 dan Gambar 12 untuk panjang penyaluran $20 \mathrm{~cm}$.

Berbeda dengan panjang penyaluran $20 \mathrm{~cm}$, pola retak yang terjadi antara bagian sisi depan dan sisi belakang portal pada panjang penyaluran $40 \mathrm{~cm}$ memiliki kesamaan bentuk retakan, yaitu sejajar dengan panjang penyaluran bagian bawah (daerah tarik). Selain itu pola retak lebih menyebar dan sedikit serta tidak terkonsentrasi pada joint balok-kolom. Pola retak menyebar dan tidak 
terkonsentrasi pada daerah joint balok-kolom serta retakan yang terjadi sedikit merupakan pola retak yang dianjurkan, karena kemungkinan akan keruntuhan secara tiba-tiba tidak terjadi.

Dari hasil uji eksperimen dan analisa, diketahui bahwa retak yang tejadi pada panjang penyaluran $20 \mathrm{~cm}$ yang lebih rapat dan terkonsentrasi pada joint balok-kolom. Hal ini disebabkan oleh beban yang diterima oleh panjang penyaluran $20 \mathrm{~cm}$ pada awal perpindahan lebih besar dari pada panjang penyaluran $40 \mathrm{~cm}$. Selain itu ikatan antara tulangan dan beton juga mempengaruhi kerapatan dari retakan.

Perbedaan lainnya retak pada panjang penyaluran $20 \mathrm{~cm}$ terjadi pada daerah tekan sedangkan pada panjang penyaluran $40 \mathrm{~cm}$ retak terjadi pada daerah tarik. Hal ini membuktikan bahwa panjang penyaluran $40 \mathrm{~cm}$ lebih mampu mencegah terjadinya keruntuhan pada joint balok-kolom di daerah tekan dibandingkan dengan panjang penyaluran $20 \mathrm{~cm}$.

Sedangkan dari segi besarnya beban maksimum $(P)$ yang dapat dipikul, panjang penyaluran $20 \mathrm{~cm}$ mampu menahan beban yang lebih besar pada awal-awal perpindahan hingga mencapai batas beban ultimit, setelah itu terjadi penurunan beban secara tiba-tiba (portal mengalami keruntuhan). Perilaku struktur seperti ini sangat tidak aman untuk bangunan pada daerah gempa, karena keruntuhan secara tiba-tiba dapat memakan korban jiwa yang lebih banyak. Jika dibandingkan dengan panjang penyaluran $40 \mathrm{~cm}$, deformasi yang terjadi lebih panjang dan tidak terjadi penurunan beban secara tiba-tiba. Kondisi ini sangat baik untuk daerah rawan gempa karena struktur dengan deformasi/ memiliki perpindahan yang panjang memiliki daktilitas yang baik, sehingga tidak terjadi penurunan secara tiba-tiba. Karena penelitian ini mengacu pada perencanaan rumah tahan gempa, Dimana lebih dititik beratkan pada minimalisasi jatuhnya korban jiwa, maka panjang penyaluran $40 \mathrm{~cm}$ bisa dipilih sebagai alternatif, karena kemungkinan keruntuhan secara tiba-tiba sangat kecil.
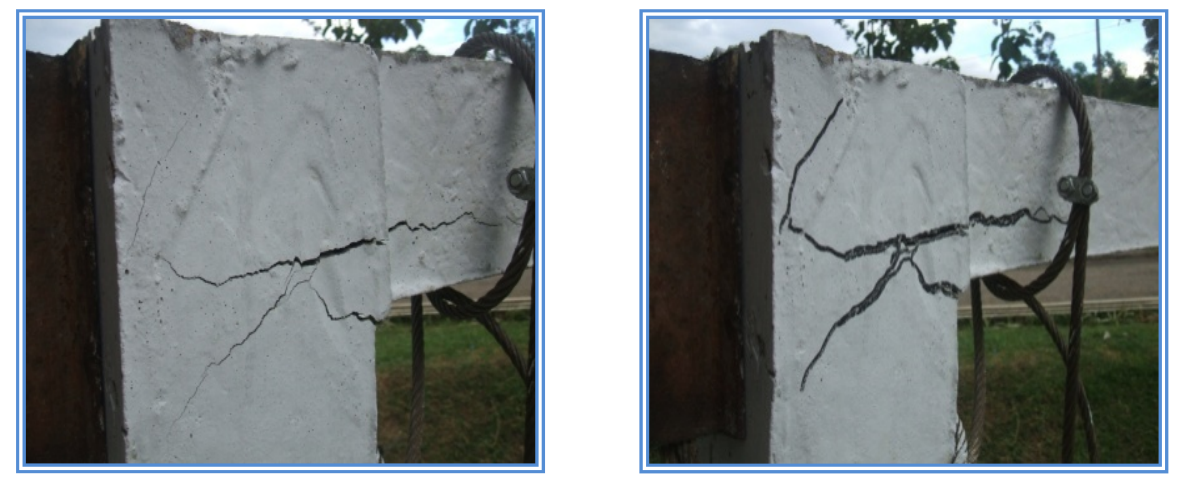

Gambar 9. Pola Retak (Tampak Depan) pada Panjang Penyaluran $40 \mathrm{~cm}$
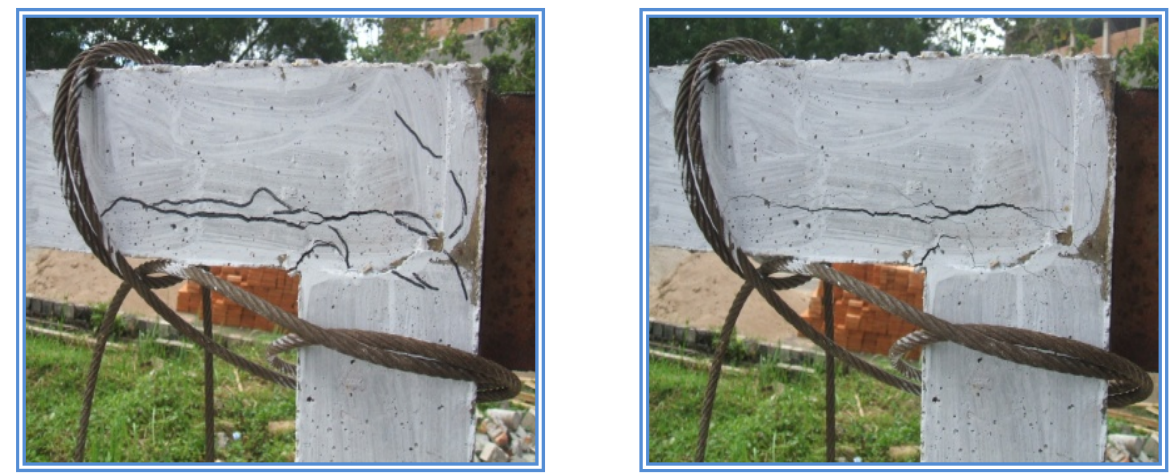

Gambar 10. Pola Retak (Tampak Belakang) pada Panjang Penyaluran 40 cm 

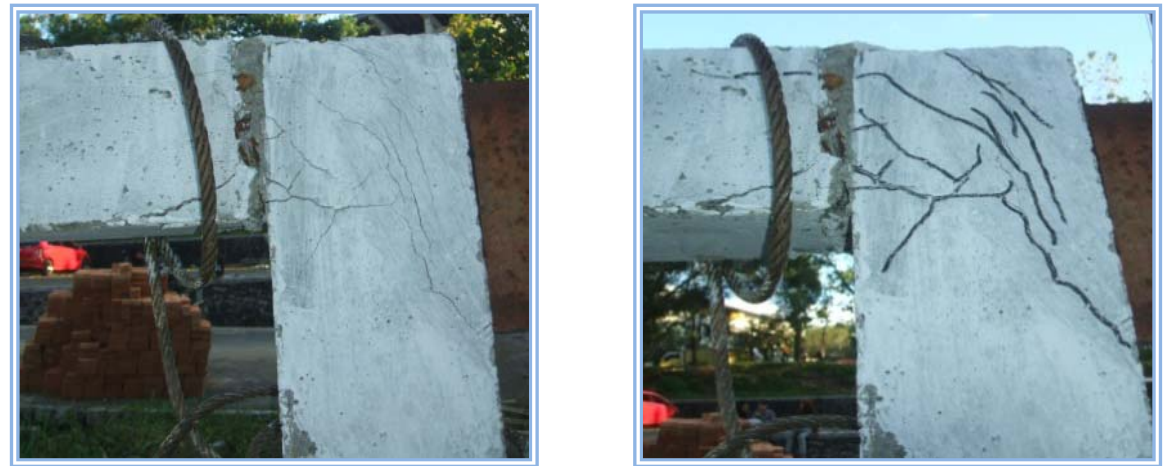

Gambar 11. Pola Retak (Tampak Depan) pada Panjang Penyaluran 20 cm
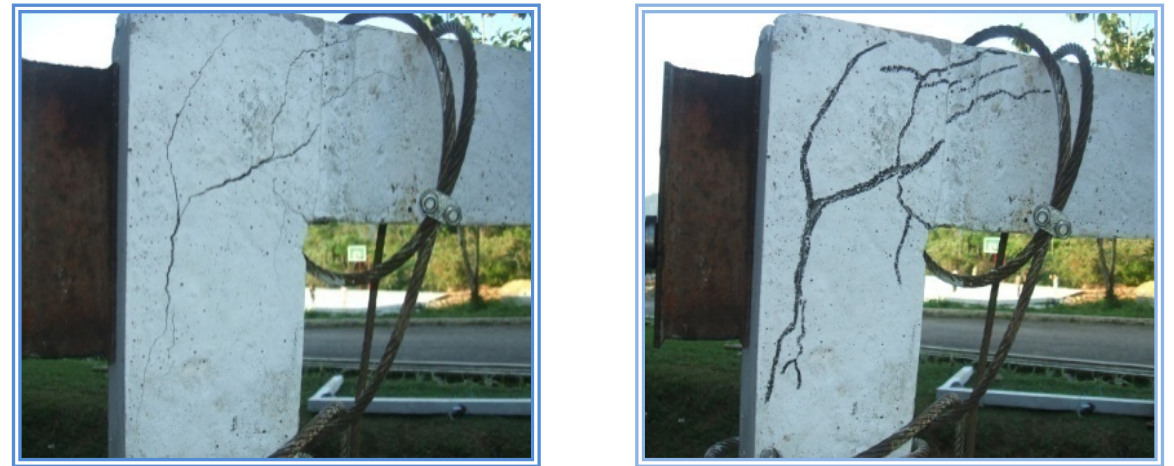

Gambar 12. Pola Retak (Tampak Belakang) pada Panjang Penyaluran 20 cm

\subsection{Analisa Tegangan dan Regangan}

Pada analisa tegangan-regangan ini ditinjau pada dua bagian penampang yaitu penampang pada kolom bagian atas dan pada penampang balok pada jarak $35 \mathrm{~cm}$ dari pangkal balok atau daerah sambungan, seperti terlihat pada Gambar 13.

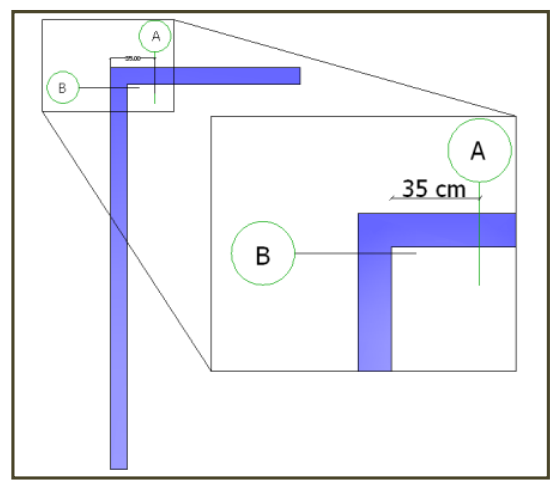

Gambar 13. Titik Tinjauan Tegangan dan Regangan Penampang

Dari pegujian yang dilakukan, didapat dua data, yaitu beban dan perpindahan. Dengan menggunakan data tersebut dapat diketahui nilai tegangan dan regangan yang terjadi. Berikut ditampilkan hasil perhitungan tegangan dan regangan dengan metoda trial and error nilai $c$ (jarak serat tekan terluar ke garis netral). Dalam analisis ini dilakukan perhitungan tegangan dan regangan pada beberapa data beban sehingga didapat diagram tegangan-regangan pada setiap titik tinjauan. 


\subsubsection{Titik A (Panjang Penyaluran $20 \mathrm{~cm}$ dan $40 \mathrm{~cm}$ )}

1). Panjang Penyaluran $40 \mathrm{~cm}$

Penambahan beban ditinjau pada titik $1-5$ diperlihatkan pada Gambar 14. Akibat dari penambahan beban tersebut terjadi perubahan tegangan dan regangan baik pada beton maupun pada baja tulangan. Pada titik ini tegangan beton yang terjadi di sepanjang lengan momen internal (C) yang diberikan sebesar 22,979 $\mathrm{kg}-190 \mathrm{~kg}$ masih dalam kondisi linier. Semakin bertambahnya beban maka nilai $C$ juga akan bertambah besar selama masih dalam kondisi linier seperti pada Gambar 15. Selain itu distribusi tegangan pada penampang balok belum mengalami retak. Pada kondisi $1-5$, tegangan beton $f_{c}$ akibat beban $P$ masih lebih kecil dari pada $f_{c}^{\prime}\left(f_{c}<f_{c}{ }^{\prime}\right)$. Selanjutnya pada tulangan nilai $f_{s}$ maksimum untuk tulangan tarik pada pengujian adalah $62.88 \mathrm{MPa}$ masih lebih kecil dari $f_{y}=240 \mathrm{MPa}$, dapat dikatakan tulangan belum leleh.

Dari segi regangan, bertambahnya beban berbanding lurus dengan penambahan regangan baik pada beton maupun baja. Berdasarkan perhitungan pada kondisi 5 nilai regangan beton $\left(\varepsilon_{c}\right)$ adalah $0,0002678 \mathrm{~mm} / \mathrm{mm}(<0.003)$. Sedangkan regangan baja pada tulangan tarik dan tekan masingmasing 0,000314 dan 0,000129 masih lebih kecil dari $\varepsilon_{y}$ yaitu 0,0012. Dengan kata lain, baja tulangan masih dalam kondisi elastis seperti yang ditunjukkan pada Gambar 16 dan Gambar 17. Jika perhitungan secara analisis dilanjutkan maka baja tulangan tarik kondisi leleh $\left(\varepsilon_{s}=\varepsilon_{y}=\right.$ $0,0012)$ pada saat tegangan beton $\left(f_{c}^{\prime}\right) 15,4 \mathrm{MPa}$. Seperti pada. Secara analisis dapat disimpulkan bahwa beban maksimum $190 \mathrm{~kg}$ pada eksperimen belum mengakibatkan beton retak/ hancur pada daerah tekan dan tulangan baja belum leleh.

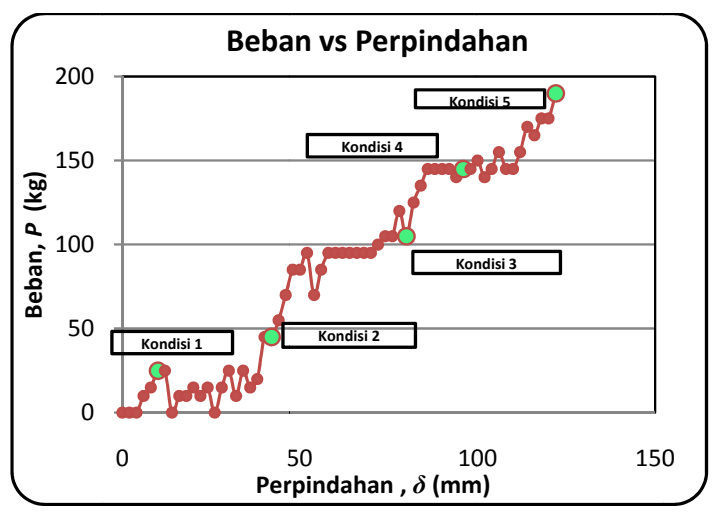

Gambar 14. Titik Tinjauan

Panjang Penyaluran $40 \mathrm{~cm}$

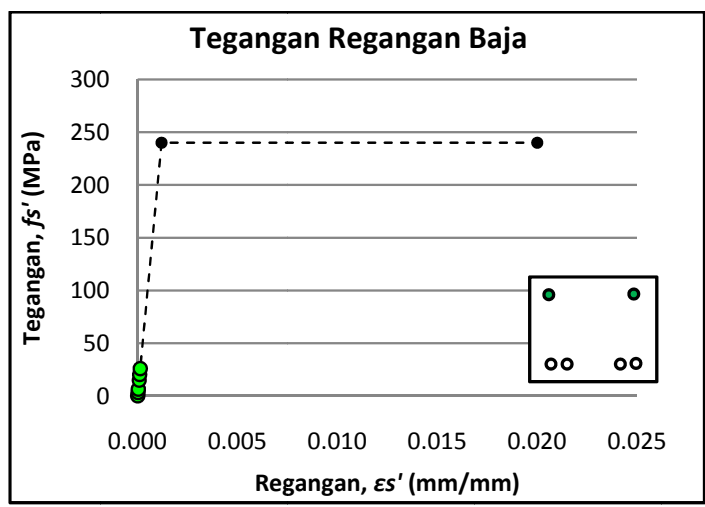

Gambar 16. Kondisi Tegangan - Regangan Tulangan Baja Bagian Atas

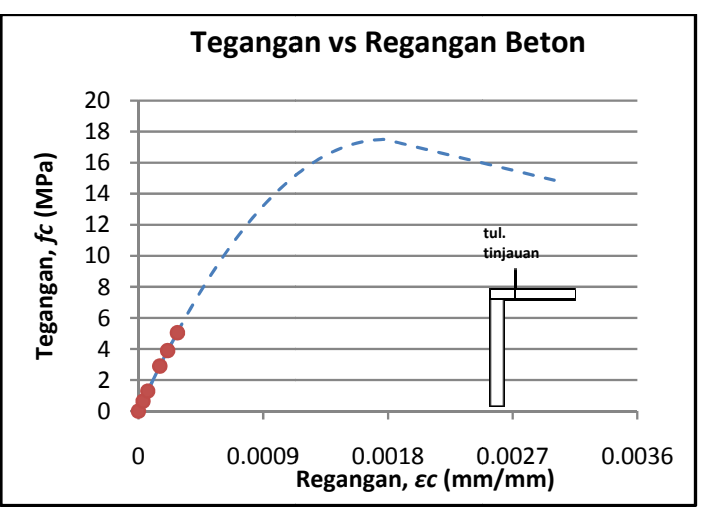

Gambar 15. Plot Titik Tegangan-Regangan ke Grafik Hognestad

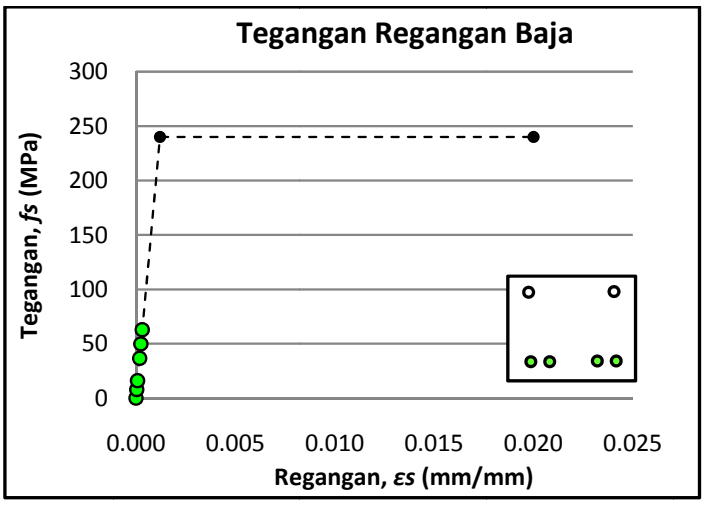

Gambar 17. Kondisi Tegangan-Regangan Tulangan Baja Bagian Bawah 
2). Panjang Penyaluran $20 \mathrm{~cm}$

Gambar 18 menunjukkan kondisi dimana tegangan dan regangan penampang saat diberi beban pushover. Pada pembebanan maksimum sebesar 155,3 kg kondisi tegangan-regangan beton masih dalam kondisi linier seperti pada Gambar 19. Selain itu distribusi tegangan pada penampang balok belum mengalami retak. Pada kondisi 1 - 5 tegangan beton $f_{c}$ akibat beban $P$ masih lebih kecil dari pada $f_{c}^{\prime}\left(f_{c}<f_{c}\right)$. Sama halnya dengan tulangan tarik pada balok nilai tegangan tarik maksimum $\left(f_{s}\right)$ pada pengujian adalah 99,21 $\mathrm{MPa}\left(f_{s}<f_{y}\right)$.

Dari segi regangan pada kondisi 5 (beban maksimum saat pengujian) regangan beton adalah $0,000277 \mathrm{~mm} / \mathrm{mm}$ masih lebih kecil dari pada regangan maksimum beton 0,003 . Selain itu regangan yang terjadi pada tulangan juga belum melebihi regangan leleh $\left(\varepsilon_{y}\right)$ yaitu 0,0012 , dimana nilai dari regangan baja $\left(\varepsilon_{s}\right.$ dan $\left.\varepsilon_{s}{ }^{\prime}\right)$ masing-masing $0,000496 \mathrm{~mm} / \mathrm{mm}$ dan $0,000093 \mathrm{~mm} / \mathrm{mm}$. Sama halnya dengan panjang penyaluran $40 \mathrm{~cm}$, untuk panjang penyaluran $20 \mathrm{~cm}$ baja tulangan tarik dan tekan masih dalam kondisi elastis (linier) diperlihatkan pada Gambar 20 dan Gambar 21.

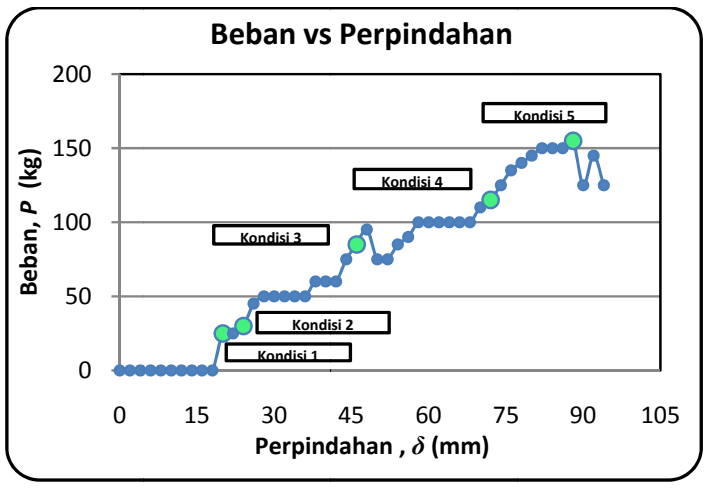

Gambar 18. Titik Tinjauan Panjang Penyaluran $20 \mathrm{~cm}$

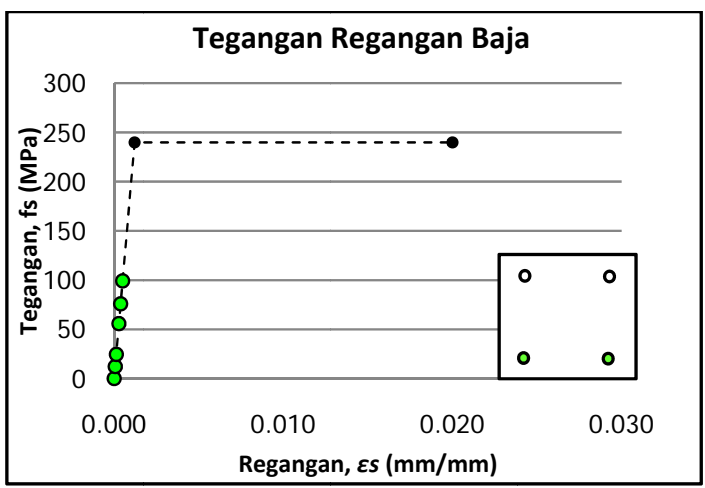

Gambar 20. Kondisi Tegangan-Regangan Tulangan Baja Bagian Atas

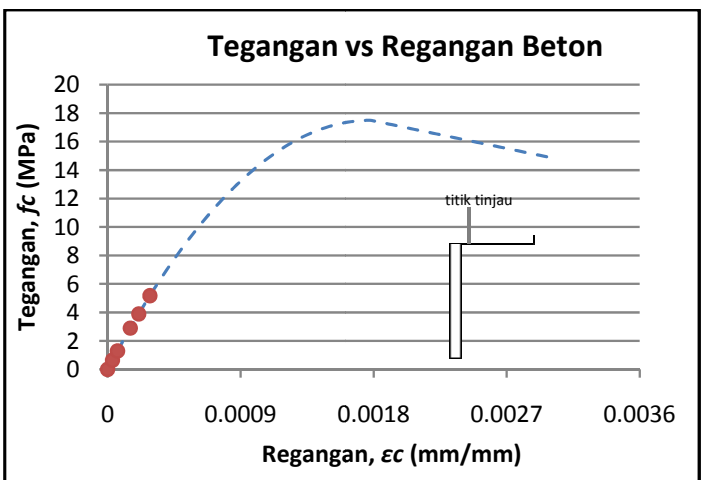

Gambar 19. Plot Titik Tegangan-Regangan Beton ke Grafik Hognestad

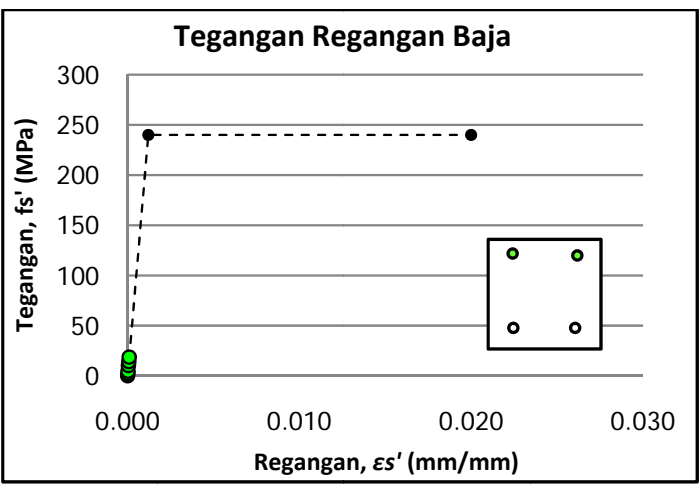

Gambar 21. Kondisi Tegangan-Regangan Tulangan Baja Bagian Atas

\subsubsection{Titik B (Panjang Penyaluran $20 \mathrm{~cm}$ dan $40 \mathrm{~cm}$ )}

Tinjauan pada daerah kolom untuk setiap pertambahan beban diperlihatkan pada Gambar 22 untuk panjang penyaluran $40 \mathrm{~cm}$ dan Gambar 23 untuk panjang penyaluran $20 \mathrm{~cm}$. Berdasarkan hasil perhitungan, untuk panjang penyaluran $40 \mathrm{~cm}$ beban maksimum yang diberikan saat pengujian $155,8 \mathrm{~kg}$ masih terlalu kecil karena tegangan beton $\left(f_{c}\right)$ yang diperoleh masih lebih kecil dari pada kuat tekan beton $\left(f_{c}^{\prime}\right)$ yaitu $7,45 \mathrm{MPa}$ (Gambar 24). Untuk tulangan tarik dan tulangan tekan, tegangan maksimum tulangan yang terjadi saat pengujian masing-masing sebesar 151,94 MPa dan 
$27,15 \mathrm{MPa}$, sehingga dapat diartikan tulangan tarik dan tekan masih dalam kondisi elastis (belum leleh) seperti pada Gambar 25 dan Gambar 26.

Sama halnya dengan panjang penyaluran $40 \mathrm{~cm}$, untuk panjang penyaluran $20 \mathrm{~cm}$ grafik teganganregangan beton dan baja tulangan masih dalam kondisi linier (Gambar 25). Karena nilai $f_{c}$ pada kondisi 5 (Gambar 24) masih lebih kecil dari pada kuat tekan beton $\left(f_{c}{ }^{\prime}\right)$. Begitu pula untuk nilai $f_{s}$ masih lebih kecil dari pada tegangan leleh baja $\left(f_{y}\right)$ yaitu $240 \mathrm{MPa}$.

Dari penjelasan di atas dapat disimpulkan bahwa beban maksimum yang diberikan pada pengujian masih terlalu kecil, sehingga beton belum mengalami retak pada daerah tekan dan tulangan leleh belum mengalami.

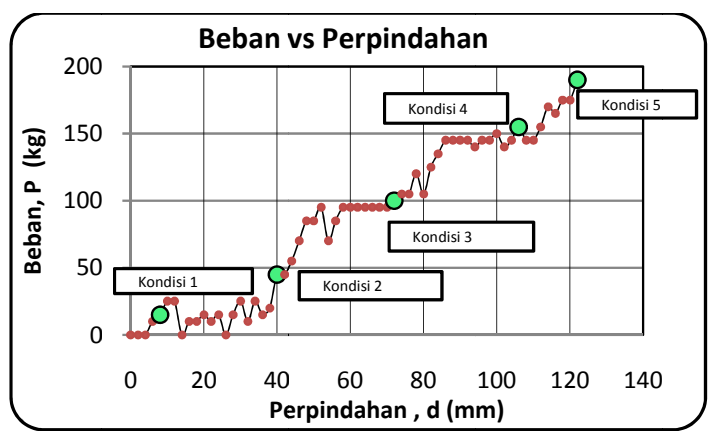

Gambar 22. Titik Tinjauan Panjang Penyaluran $40 \mathrm{~cm}$

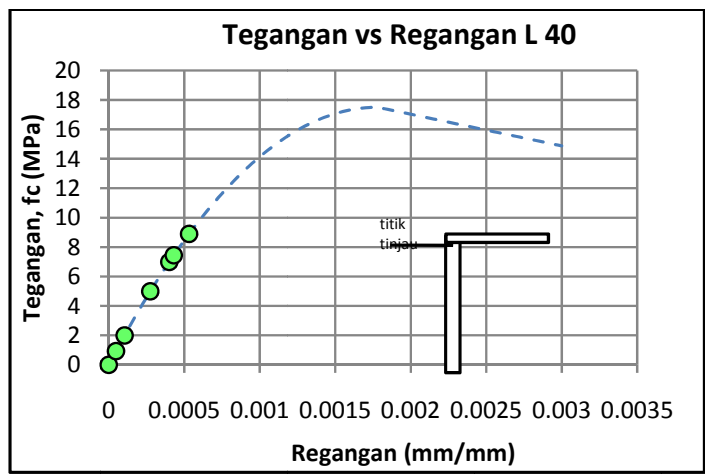

Gambar 24. Plot Titik Tegangan-Regangan ke Grafik Hognestad

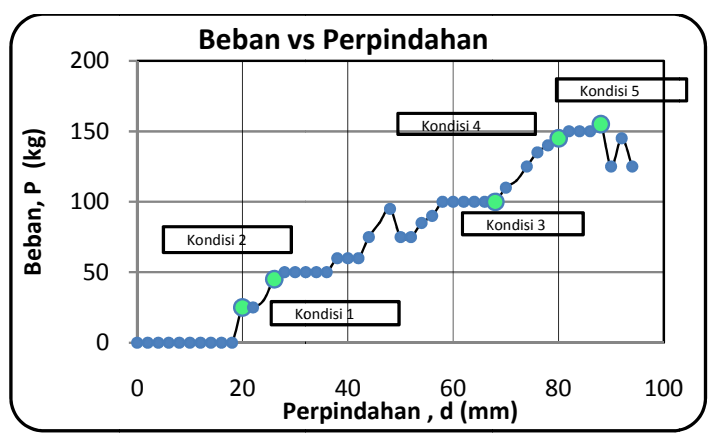

Gambar 23. Titik Tinjauan Panjang Penyaluran $20 \mathrm{~cm}$

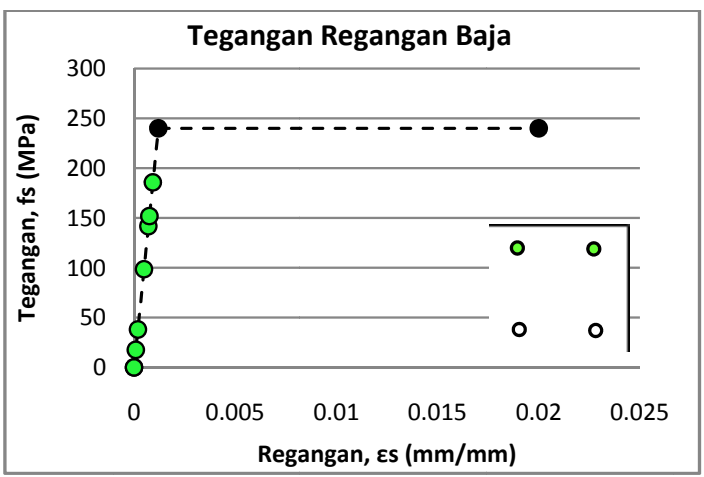

Gambar 25. Kondisi Tegangan-Regangan Tulangan Baja Tarik

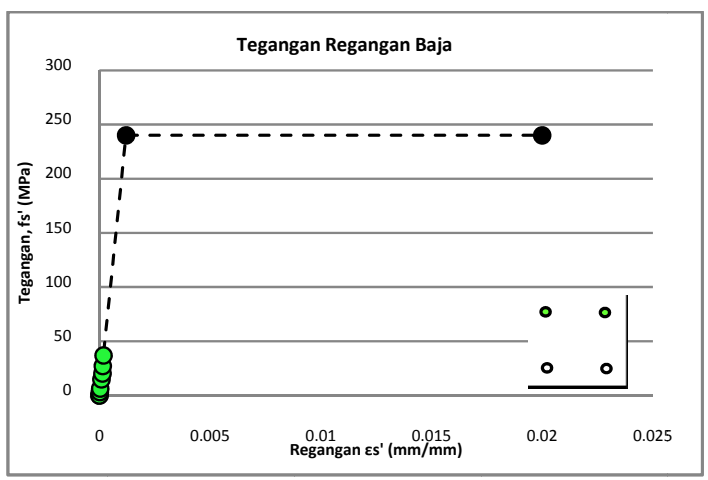

Gambar 26. Kondisi Tegangan-Regangan Tulangan Baja Tekan 


\section{KESIMPULAN}

Berdasarkan hasil studi eksperimental tersebut di atas, dapat diperoleh beberapa kesimpulan sebagai berikut :

1. Panjang penyaluran $40 \mathrm{~cm}$ mampu memikul beban maksimum $\left(P_{\text {maks }}\right)$ lebih besar dibandingkan dengan panjang penyaluran $20 \mathrm{~cm}$.

2. Pola retak pada panjang penyaluran $20 \mathrm{~cm}$ berbentuk diagonal dan terkonsentrasi pada joint sedangkan pada panjang penyaluran $40 \mathrm{~cm}$ pola retak lebih menyebar (tidak terkonsentrasi pada joint balok-kolom) dan menjalar ke daerah balok.

3. Berdasarkan analisis tegangan-regangan beton dan baja tulangan, kedua sampel uji masih dalam kondisi linier/elastis.

4. Berdasarkan hasil perhitungan, kedua sampel uji mengalami keruntuhan tarik (under reinforce) karena tulangan mencapai kuat lelehnya terlebih dahulu.

5. Baja tulangan untuk panjang penyaluran $20 \mathrm{~cm}$ mencapai kuat leleh terlebih dahulu jika dibandingkan dengan penjang penyaluran $40 \mathrm{~cm}$.

6. Baja tulangan pada titik tinjau B (pada kolom) lebih dahulu mencapai kuat leleh dari pada baja tulangan pada titik tinjau A (pada balok). Sehingga perlu adanya panjang penyaluran dari balok ke kolom.

\section{DAFTAR PUSTAKA}

Boen, T., (1983), Manual Bangunan Tahan Gempa (Rumah Tinggal), Yayasan Lembaga Penyelidikan Masalah Bangunan.

Boen T., (2000), Bangunan Rumah Tinggal Sederhana : Belajar dari Kerusakan Akibat Gempa, Prosiding Lokakarya Nasional Bangunan Sederhana Tahan Gempa, UII, Yogyakarta.

Boen T., (2000), Gempa Bumi Bengkulu : Fenomena dan Perbaikan/ Perkuatan Bangunan (Bedasarkan Hasil Pengamatan Bangunan yang Rusak akibat Gempa Bumi Bengkulu 4 Juni 2000, Teddy Boen dan Rekan, Jakarta.

Boen,T., (1994), Manual Perbaikan Bangunan Sederhana yang Rusak akibat Gempa Bumi.

SNI 03-1726-2002, Tata Cara Perencanaan Ketahanan Gempa untuk Bangunan.

SNI 03-6816-2002, Tata Cara Pendetailan Penulangan Beton Bertulang Indonesia. 